\title{
Oxidative stress biomarkers and asthma characteristics in adults of the EGEA study
}

Miora Andrianjafimasy ${ }^{1,2}$, Farid Zerimech ${ }^{3,4}$, Zeina Akiki ${ }^{1,2}$, Helene Huyvaert ${ }^{3}$, Nicole Le Moual $^{1,2}$, Valérie Siroux ${ }^{5}$, Régis Matran ${ }^{6,7}$, Orianne Dumas ${ }^{1,2}$, Rachel Nadif $^{1,2}$

\section{Affiliations:}

1. INSERM, U1168, Aging and chronic diseases. Epidemiological and Public health approaches, F-94807 Villejuif, France

2. Univ Versailles St-Quentin-en-Yvelines, UMR-S 1168, F-78180 Montigny-le-Bretonneux, France

3. CHU Lille, Service de Biochimie et Biologie moléculaire, F-59000 Lille, France

4. Université de Lille, EA4483, IMPECS, Institut Pasteur de Lille, F-59000 Lille, France

5. Institute for Advanced Biosciences, Centre de recherche UGA-Inserm U1209-CNRS UMR 5309, équipe d'épidémiologie environnementale, Site Santé, Allée des Alpes, F-38700 La Tronche, France

6. CHRU de Lille, F-59000 Lille, France

7. Univ Lille Nord de France, F-59000 Lille, France

\section{Corresponding author:}

Miora Andrianjafimasy, INSERM, U1168, Aging and chronic diseases. Epidemiological and Public health approaches, F-94807 Villejuif, France

Phone number: 33 (0) 145595073

Email : miora.andrianjafimasy@inserm.fr 


\begin{abstract}
Asthma is an oxidative stress-related disease but associations with asthma outcomes are poorly studied in adults.
\end{abstract}

We aimed to study the associations between several biomarkers related to oxidative stress and various asthma outcomes.

Cross-sectional analyses were conducted in 1388 adults (43 years old, $44 \%$ with asthma) from the Epidemiological Study on the Genetics and Environment of Asthma (EGEA2). Three blood antioxidant enzyme activities (biomarkers of response to oxidative stress) and exhaled breath condensate 8-isoprostanes and plasma Fluorescent Oxidation Products (F1OPs) levels (two biomarkers of damage) were measured. Associations between biomarkers and 1) ever asthma, and 2) among participants with asthma, asthma attacks, asthma control, and lung function, were evaluated by regression models adjusted for age, sex and smoking.

Biomarkers of response were unrelated to asthma outcomes. Higher 8-isoprostanes level was significantly associated with ever asthma (odds ratio for one interquartile range increase $[95 \%$ CI] 1.28 [1.06-1.67]). Among participants with asthma, 8-isoprostanes level was negatively associated with adult-onset asthma (0.63 [0.41-0.97]) and F1OPs level was positively associated with asthma attacks $(1.33$ [1.07-1.65]), poor asthma control (1.30 [1.02-1.66]), and poor lung function $(1.34[1.04-1.74])$. 
Results suggest 8-isoprostanes to be involved in childhood-onset asthma and FlOPs to be linked to asthma expression. 
Words count: abstract 199 words, main text 3501 words

Key words: asthma characteristics, adults, biomarkers, oxidative stress, epidemiology

Take home message: Oxidative stress-related damages seem to be involved in asthma expression and control.

\section{Plain language summary:}

Asthma is an oxidative stress-related disease but few studies are available on the associations with asthma characteristics, particularly in adults. The aim of this study is to assess the associations between biomarkers of response or of damage related to oxidative stress and various asthma outcomes.

Results showed that biomarkers of response were not associated with any asthma outcomes. 8isoprostanes level was higher in adults with ever asthma, while Fluorescent oxidation products (F1OPs) level, a global marker of oxidation process, was higher in adults with poor asthma outcomes and poor lung function.

Our study suggests 8-isoprostanes and FlOPs as biomarkers of interest for studying oxidative stress-related damage in chronic diseases such as asthma. 


\section{Introduction}

Asthma is a chronic airway inflammatory disease affecting about 350 million people worldwide [1]. This heterogeneous disease $[2,3]$ is now studied at cellular and molecular levels, offering new opportunities for its prevention and control [4, 5]. Oxidative stress, which reflects an imbalance between increased exposure to reactive oxygen species (ROS) and antioxidant defense, is involved in the pathophysiological mechanism of asthma [6]. In asthma, ROS are produced endogenously by metabolic reactions $[7,8]$ and exogenously by environmental factors (e.g., air pollutants, smoking) $[8,9]$.

To neutralize overproduction of ROS, the organism develops antioxidant defense through an enzymatic system including superoxide dismutase (SOD) coupled to catalase and glutathione peroxidase (GPX) $[10,11]$. These antioxidant enzymes, which are the first line of defense against the ROS, are biomarkers of interest in the response to oxidative stress [8]. In addition, ROS interact with lipids of cells membranes, especially arachidonic acid, releasing 8-isoprostanes, the end-products of lipid peroxidation [12]. However, few studies are available on the associations between biomarkers of response (SOD, GPX and catalase) [13-16] or biomarkers of damage (8isoprostanes) $[6,12]$ and asthma characteristics particularly in adults, and their results are discordant.

Fluorescent oxidation products (FlOPs) level, a global biomarker of oxidation processes including protein and DNA oxidation and lipid peroxidation [17], is of growing interest in epidemiology. This biomarker of damage was found more recently to be associated with chronic diseases [18] such as coronary heart disease [19] and chronic kidney disease [17]. Nevertheless, to our knowledge, no studies have been conducted to evaluate the association between FlOPs and asthma. 
Taking advantage of the extensive biological and phenotypic characterization of more than 1000 adults in the EGEA study, we aimed to investigate the associations between biomarkers of response and damage related to oxidative stress, measured from different biological compartments, and asthma outcomes. 


\section{Methods}

\section{Population and study design}

The Epidemiological study on the Genetics and Environment of Asthma (EGEA) is a French cohort study with three surveys over 20 years. The first EGEA survey (EGEA1) included cases with asthma, recruited in five chest clinics, their first-degree relatives and population-based controls, recruited in the early 90's in 5 French cities (total: n=2047). A follow-up of the participants has been completed in 2003-2007 (EGEA2), including 1601 subjects with complete examination, almost exclusively adults. At each survey, all subjects responded to a questionnaire based on international standardized tools to diagnose asthma and to determine respiratory and allergic symptoms, treatments, and environmental exposures. The protocol and descriptive characteristics have been described previously [20, 21]. EGEA collection is certified ISO 9001 and referenced in the Biobank network [22].

The present analyses used data collected at EGEA2. Only adult participants ( $\geq 16$ years old) with available data on measurement of any biomarker and smoking status were included $(\mathrm{n}=1388$, supplementary Figure E1). Among adults, participants not included in the analyses $(\mathrm{n}=183)$ were similar to those included regarding age, sex, smoking status, body mass index (BMI) and asthma characteristics (supplementary Table E1).

\section{Asthma outcomes}


Asthma cases were participants who had positive responses to four questions from the validated and standardized British Medical Research Council, European Coal and Steel Community, American Thoracic Society (ATS) and European Community Respiratory Health Survey questionnaires: "Have you ever had attacks of breathlessness at rest with wheezing?", "Have you ever had asthma attacks?", "Was this diagnosis confirmed by a physician?" and "Have you had an asthma attack in the last 12 months?", or a positive response to at least two questions and a positive review of medical records. Asthma in first-degree relatives of cases was defined as a positive answer to at least one of the first two questions [21, 23]. Among the 614 participants with ever asthma included in the present analysis, $536(87.3 \%)$ had a diagnosis of asthma confirmed by a physician. Among participants with ever asthma, current asthma was defined by the report of respiratory symptoms (wheeze, nocturnal chest tightness, attacks of breathlessness following strenuous activity, at rest or at nighttime) or asthma attacks or use of inhaled and/or oral medicines because of breathing problems in the past twelve months [24]. Asthma control has been assessed over a 3 month period as previously [25], as closely as possible from the Global Initiative for Asthma 2015 definition, based on frequency of daytime/nighttime symptoms, use of reliever medication and activity limitations. Asthma exacerbations were defined by hospital or emergency admissions because of respiratory problems or use of oral steroids for breathing difficulties in the past twelve months [26].

More details on the definition of asthma outcomes, lung function, medication use, allergic and inflammatory characteristics are provided in online supplementary materials.

\section{Biomarkers related to oxidative stress}




\section{Biomarkers of response}

Erythrocyte antioxidant enzyme activities were measured as previously $[27,28]$ according to standardized procedures. The enzymatic activity was expressed in $\mathrm{U} / \mathrm{g}$ of hemoglobin $(\mathrm{Hb})$ for SOD and GPX and in $\mathrm{k} / \mathrm{g} \mathrm{Hb}$ for catalase (1k corresponds to the rate constant of the first order reaction). All samples were analysed in duplicate or triplicate at the Laboratory of Biochemistry Molecular Biology of CHRU de Lille according to validated and standardized procedures. The coefficient of variation was $<10 \%$ for each enzymatic assay.

\section{Biomarkers of damage}

Exhaled breath condensate (EBC) was collected with an RTubeTM according a standardized method as previously described [22]. Briefly, the RTube (TM) was rinsed with deionized water and dried thoroughly. Participants breathed orally at tidal volumes into a mouthpiece attached to a cold condenser $\left(-20^{\circ} \mathrm{C}\right)$. They were seated comfortably with a headrest. All headrests and back seats were tilted slightly to avoid any saliva contamination during breathing maneuvers. Breathing was quiet and regular. After 15 minutes, EBC collection was immediately separated in aliquots and stored at $-80^{\circ} \mathrm{C}$ according to standardized procedures.

8-isoprostanes level was measured in EBC with a specific enzyme immunoassay (EIA) kit (8isoprostanes EIA kit, Cayman Chemical, Ann Arbor, MI, USA) according to the manufacturer's

protocol. $50 \mu \mathrm{L}$ of unextracted $\mathrm{EBC}$ was assayed in duplicate and the 8-isoprostanes level was calculated from a calibration curve obtained from the eight calibration points $(0.8-2.0-5.1-12.8$ 32-80-200-500 pg/mL where $0.8 \mathrm{pg} / \mathrm{ml}$ is the lower point). The lower limit of detection for 8 isoprostanes was $4.0 \mathrm{pg} / \mathrm{mL}$ and the intra-assay coefficient of variation was less than $20 \%$. 
Plasma FlOPs level was measured as previously described [18, 29]. Briefly, plasma was extracted into a mixture of ethanol/ether $(3 / 1, \mathrm{v} / \mathrm{v})$ and measured using a spectrofluorimeter $(360 \mathrm{~nm}$ excitation wavelength, 430nm emission wavelength). Fluorescence was expressed as a unit of relative fluorescence intensity per milliliter of plasma $(\mathrm{RFU} / \mathrm{mL})$.

Inter-plate variability, storage time and diurnal variation did not affect any of the biomarkers levels (data not shown). More details on blood and EBC collection as well as measurement of biomarkers are provided in online supplementary data.

\section{Statistical analyses}

SOD, GPX, FlOPs and 8-isoprostanes were log-transformed due to their skewed distribution and expressed as geometric mean (GM) and Q1-Q3.

Associations between each biomarker and age, sex, BMI and smoking status were studied in participants without asthma, in order to evaluate these associations independently of the disease.

We used regression models to investigate the associations between each biomarker and asthma ever in all participants; and between each biomarker and asthma characteristics, pulmonary function, allergic and inflammatory characteristics in participants with ever asthma. "Partly controlled" and "uncontrolled" asthma were regrouped in one class, due to the small number of asthmatics in the uncontrolled group.

Regression analyses were conducted using generalized estimated equations (GEEs) to take into account familial dependence between individuals. Multiple regression models considered age (continuous), sex and smoking status (never-, ex- or current smokers) as potential confounders. A 
sensitivity analysis on the association between FlOPs level and asthma outcomes was performed with adjustment for heavy smoking expressed as number of cigarette packs per year or daily tobacco consumption (g/day) instead of smoking status.

To facilitate result interpretations, we rescaled the biomarker levels using interquartile range (IQR), defined as the distance between the 25 th and 75 th percentiles and compared participants with a typical "high" level of biomarker to participants with a typical "low" level.

Statistical analyses were performed using SAS statistical software (version 9.3; SAS Institute, Inc., Cary, NC, USA). A p-value of less than 0.05 was considered statistically significant. 


\section{Results}

\section{Characteristics of the participants}

Table 1 shows the characteristics of the 1388 participants included in the analyses. Among them, 614 had ever asthma. Their mean age was 43 years, 51\% were women and 23\% were smokers. Participants with ever asthma were more often men $(\mathrm{p}=0.01)$ and younger than participants without asthma $(\mathrm{p}<0.0001)$. They also had higher rate of allergic sensitization, lower $\mathrm{FEV}_{1}$ and higher bronchial hyperresponsiveness than participants without asthma (all $p<0.0001$ ).

Among participants with ever asthma, 89\% had current asthma, 32\% had partly controlled asthma and $11 \%$ had uncontrolled asthma, $34 \%$ had an age of asthma onset $\geq 16$ years; in the past 12 months, 66\% reported use of any asthma treatments (inhaled or oral medicines), $40 \%$ reported use of inhaled corticosteroids (ICS), 38\% had asthma attacks, 14\% reported having had asthma exacerbations and $78 \%$ reported having had respiratory symptoms.

In all participants, the geometric means [Q1; Q3] of biomarkers of oxidative stress were: 1218 [1036; 1449] U/g Hb for SOD, 39.1 [34.2; 45.3] U/g Hb for GPX; mean (SD) of catalase was 163 (40.4) $\mathrm{k} / \mathrm{g} \mathrm{Hb}$. The geometric means of 8 -isoprostanes were $2.88[1.31 ; 6.66] \mathrm{pg} / \mathrm{mL}$ and 93.3 $[79.9 ; 106] \mathrm{RFU} / \mathrm{mL}$ for FlOPs.

\section{Description of biomarkers of oxidative stress in participants without asthma}


Among biomarkers of response, catalase activity was higher among those with higher BMI $\left(\mathrm{p}_{\text {trend }}=0.02\right)$ and was higher in current and ex-smokers than in non-smokers $\left(\mathrm{p}_{\text {trend }}=0.004\right)$. However, no significant association was observed between catalase and heavy smoking. GPX activity was positively associated with age $\left(\mathrm{p}_{\text {trend }}=0.01\right)$ and was higher in women than in men $(\mathrm{p}<0.0001)$. SOD activity was negatively associated with age $\left(\mathrm{p}_{\text {trend }}<0.0001\right)$ and positively associated with BMI ( $\left.\mathrm{p}_{\text {trend }}=0.003\right)$ (supplementary table E2).

Among biomarkers of damage, 8-isoprostanes level was negatively associated with age ( $\mathrm{p}_{\text {trend }}=0.01$ ), and was higher in women than in men $(\mathrm{p}=0.04)$. FlOPs level was positively associated with age $\left(\mathrm{p}_{\text {trend }}<0.0001\right)$ and was higher in current and ex-smokers than in nonsmokers $\left(\mathrm{p}_{\text {trend }}<0.0001\right)$ (supplementary table E3). Furthermore, in current and ex-smokers, FlOPs level was positively associated with the number of packs of cigarettes per year $\left(\mathrm{p}_{\text {trend }}=0.03\right)$; and in current smokers, FlOPs level was positively associated with daily tobacco consumption $\left(\mathrm{p}_{\text {trend }}=0.001\right)$ (supplementary figure $\left.\mathrm{E} 2\right)$.

\section{Associations between biomarkers and asthma status}

The distribution of each biomarker according to ever asthma is shown in figure 1 and figure 2 . There was no significant difference in SOD, GPX or catalase activities according to ever asthma. In contrast, 8-isoprostanes level was higher and FlOPs level was lower in participants with ever asthma compared to those without asthma. After adjustment for age, sex and smoking status, only the association between 8-isoprostanes level and ever asthma remained significant (table 2). 


\section{Associations between biomarkers and asthma outcomes among participants with ever asthma}

Among participants with ever asthma, there was no significant association between SOD, GPX and catalase activities and asthma outcomes or lung function (supplementary table E4).

In contrast, biomarkers of damage were associated with several asthma outcomes (table 2). Lower level of 8-isoprostanes was significantly associated with adult-onset asthma compared to childhood-onset. No other significant associations were found.

Higher FlOPs level was significantly associated with adult-onset asthma, poor asthma control, asthma attacks, any asthma treatment and use of inhaled corticosteroids in the past 12 months. Furthermore, a significant positive association was observed between FlOPs level and poor lung function. Consistently, FlOPs level was negatively correlated with $\mathrm{FEV}_{1}(\mathrm{r}=-0.16, \mathrm{p}=0.0001)$. All these associations remained significant after adjustment for age, sex and smoking status, except for the association between FlOPs and adult-onset asthma. No significant association was found between FlOPs level and respiratory symptoms (table 2). Results were unchanged when we adjusted for age, sex and heavy smoking expressed as number of pack-years or daily tobacco consumption (data not shown).

Among participants with ever asthma, no significant association was observed between any biomarkers and bronchial hyperresponsiveness.

Associations between biomarkers of damage, allergic sensitization and markers of inflammation 
In participants with ever asthma, we also studied the association between biomarkers of damage and allergic sensitization markers (total $\operatorname{IgE}$ or $\mathrm{SPT}+$ ), and did not observed any significant association (table 3).

In addition, we studied the association between biomarkers of damage and blood neutrophil and eosinophil counts (table 3). No significant associations were observed between any biomarkers and eosinophil counts. However, a positive significant association was observed between FlOPs level and high neutrophil counts $\left(\geq 5000\right.$ vs. $<5000$ cells $\left./ \mathrm{mm}^{3}\right)$. Consistently, we observed a positive correlation between FlOPs and neutrophils count $(\mathrm{r}=0.12, \mathrm{p}=0.005)$. 


\section{Discussion}

The present study investigated the associations between biomarkers related to oxidative stress and various asthma outcomes. We found no significant association between any biomarkers of response and asthma outcomes. Regarding biomarkers of damage, a positive and significant association was observed between 8-isoprostanes level and ever asthma. Among participants with ever asthma, we showed for the first time a significant and positive association between 8 isoprostanes and childhood-onset asthma, while significant positive associations were shown between FlOPs level and poor asthma control, asthma attacks, any asthma treatments, poor lung function and neutrophilic asthma.

The main strength of our study was the investigation of the association between several biomarkers either involved in the response to oxidative stress or related to its damages, and various asthma characteristics. Indeed, while biomarkers of response are intracellular and reflect activities of antioxidant enzymes [8], they take part at the beginning of the "oxidative stress chain" $[30,31]$ in the continuum between environment and the disease. On the other hand, FlOPs are a global marker of oxidative stress, reflecting a mixture of oxidation products from DNA, proteins, and lipids [18], and 8-isoprostanes are a specific products of lipid peroxidation [32]. These two biomarkers of damage take part at the end of the "oxidative stress chain" and are more likely to be associated with asthma. Furthermore, we studied oxidative stress at the systemic level and close to the lung in exhaled breath condensate. Most of the participants with asthma were recruited in chest clinics as asthma cases, with a careful procedure set up to include true asthmatics using standardized and validated questionnaires. Others were recruited as first-degree relatives of asthmatic cases, based on answers to questions on asthma diagnosis. This leads to a 
group of asthmatics with wide range of severity and response to methacholine. The detailed phenotypic characterization included various asthma outcomes, which have been rarely studied in relation to oxidative stress biomarkers. No follow-up bias related to the asthma status and asthma-related phenotypes was shown in the EGEA study, and the adult asthmatics included in the present study are representative of the original study population of asthmatic cases and their first degree relatives with asthma. Oxidant /antioxidant status, and thus biomarker levels, depend on the ability of each individual to counter oxidative reactions involving genetic factors, lifestyle and environmental factors. Although not all these parameters were taken into account in our analysis and unmeasured confounding can never be ruled out, we have adjusted for relevant potential confounders such as age, sex and smoking status, thought to be associated with the biomarkers we studied.

We did not find any significant association between erythrocyte SOD, GPX and catalase activities and asthma characteristics, in contrast with previous smaller studies ( $\mathrm{n} \sim 30$ to 150 ). In these studies, lower GPX level was consistently associated with asthma [13-15, 33]; however, for SOD and catalase, contrasted results with increased $[13,14,33]$ or decreased $[15,34]$ level according to asthma status were reported. Beside differences in technical measurements, discrepancies between results may be partly explained by differences in asthma outcomes (asthma, severe asthma or incident asthma) or in body compartments (erythrocytes, plasma or serum). The relationship between antioxidant enzymes and asthma is likely complex, involving several endogenous and exogenous factors that can influence biomarkers level. In addition, it is difficult to determine cross-sectionally whether variation in biomarker levels would be the cause or the consequence of asthma. Our null results, along with discrepant findings in the literature, 
suggest that biomarkers of response may not be the most relevant to study oxidative stress in asthma. However, longitudinal studies may provide more insight regarding this relationship.

We found a significant positive association between EBC 8-isoprostanes and ever asthma consistently with previous studies including studies of children and adults reviewed in the paper by Aldakheel et al. [12]. Overall, results suggest that 8-isoprostanes may be a relevant biomarker for studying asthma. Our findings also confirm that EBC, which shows local production of free radicals [6], is an effective noninvasive method for measuring biomarkers related to oxidative stress.

We also investigate the association between 8 -isoprostanes and asthma outcomes among participants with ever asthma. Interestingly, among participants with asthma, we observed that those with childhood-onset asthma had higher 8-isoprostanes level than those with adult-onset asthma. However, we did not observe any significant association between 8-isoprostanes and other asthma outcomes. Further, we confirm the lack of association between 8-isoprostanes and lung function or bronchial hyperresponsiveness, consistently with previous studies $[35,36]$. We hypothesized that the longer a person has had asthma (for example since childhood), the greater the tissue damage in the lungs, and that high 8-isoprostanes level reflects long-term damages or the "background" of the disease rather than its expression. However, we did not observe a significant association between asthma duration and 8-isoprostanes level (data not shown). Another hypothesis is that adult-onset asthma and childhood asthma, which are two different asthma phenotypes $[4,37]$, may have partly distinct biological mechanisms. 
We found a negative association between FlOPs level and ever asthma, although this association was no longer significant after adjustment. Among participants with ever asthma, higher FlOPs level was significantly associated with poor asthma control, poor lung function and neutrophilic asthma. Consistently, we observed a significant positive association between FlOPs level, asthma attacks, use of any asthma treatments and use of ICS in the last 12 months. However, no significant association was found with current asthma, adult-onset asthma or respiratory symptoms. To the best of our knowledge, no study on the relationship between FlOPs and asthma has been published before. Nevertheless, a significant and positive association between FlOPs and others chronic inflammatory diseases such as chronic kidney disease (CKD) [17] or coronary heart disease [19] has been reported. Our results did not change after removing participants with history of CKD or cardiovascular diseases (data not shown).

Interestingly, a significant and positive association was observed between FlOPs and neutrophilic asthma suggesting that FlOPs may be related to a non-allergic phenotype. Furthermore, in the literature as in our analyses, FlOPs were shown to be associated with irritant exposures, such as tobacco smoke ([18] and online supplementary data) or occupational exposure to irritant chemicals (e.g., cleaning products) [29], which have also been associated with non-allergic asthma phenotypes [37-40].

Based on these findings, F1OPs appear to be a good biomarker for measuring oxidative stress, a pathophysiological mechanism related to several chronic diseases. In our study, some participants were not fasting at the time of the blood collection and some potential confounders such as cholesterol were not taken into account. Although more studies are needed for the standardization 
of FlOPs measurement, our findings suggest that this oxidation marker is linked to asthma expression.

Associations of 8-isoprostanes and FlOPs with asthma outcomes appeared discrepant in our study. Indeed, after adjustment, only 8-isoprostanes were associated with ever asthma and associations with asthma outcomes also differed for these two biomarkers among participants with ever asthma. The exact mechanisms explaining these different results are beyond the scope of our epidemiological study. As noted earlier, these biomarkers belong to different biological processes, and were measured in different compartments. 8-isoprostanes are the main biomarkers of the lipid peroxidation, measured in the exhaled breath condensate - likely reflecting the composition of the airway lining fluid [6] - and may therefore better represent airway process and reflect lung inflammation. FlOPs level is a biomarker of several oxidation processes, reflecting a mixture of oxidation products from DNA, proteins and lipids. This biomarker has been measured in blood - an easily available source of a large amount of antioxidant defenses in the body [13] - and can therefore better reflect oxidation at the systemic level.

In addition, none of the biomarkers of response to oxidative stress were correlated with biomarkers of damages, and no correlation was observed between 8-isoprostanes measured in EBC and FlOPs measured in blood (data not shown). Overall, all these results highlight the interest to study biomarkers in several compartments belonging to different biological processes and suggest 8-isoprostanes and F1OPs to be complementary to assess asthma.

\section{Conclusion}


In summary, our results suggest that EBC 8-isoprostanes seem to be involved in childhood-onset asthma and FlOPs seem to be linked to asthma expression and control in adults. Immediate clinical implications could not be inferred from this epidemiologic study. However, if replicated, our findings will suggest that FlOPs levels may help identifying asthmatics with higher asthma burden. Further research is needed, especially through longitudinal studies, to determine the potential interest of measuring FlOPs level in clinical practice. 


\section{Acknowledgments}

EGEA cooperative group. Coordination: V Siroux (epidemiology, PI since 2013); F Demenais (genetics); I Pin (clinical aspects); R Nadif (biology); F Kauffmann (PI 1992-2012). Respiratory epidemiology: Inserm ex-U 700, Paris: M Korobaeff (Egea1), F Neukirch (Egea1); Inserm ex-U 707, Paris: I Annesi-Maesano (Egea1-2); Inserm ex-U 1018, Villejuif: F Kauffmann, MP Oryszczyn (Egea1-2); Inserm U 1168, Villejuif: N Le Moual, R Nadif, R Varraso; Inserm U 1209 Grenoble: V Siroux. Genetics: Inserm ex-U 393, Paris: J Feingold; Inserm U 946, Paris: E Bouzigon, F Demenais, MH Dizier; CNG, Evry: I Gut (now CNAG, Barcelona, Spain), M Lathrop (now Univ McGill, Montreal, Canada). Clinical centers: Grenoble: I Pin, C Pison; Lyon: D Ecochard (Egea1), F Gormand, Y Pacheco; Marseille: D Charpin (Egea1), D Vervloet (Egea12); Montpellier: J Bousquet; Paris Cochin: A Lockhart (Egea1), R Matran (now in Lille); Paris Necker: E Paty (Egea1-2), P Scheinmann (Egea1-2); Paris-Trousseau: A Grimfeld (Egea1-2), J Just. Data and quality management: Inserm ex-U155 (Egea1): J Hochez; Inserm U 1168, Villejuif: N Le Moual; Inserm ex-U780: C Ravault (Egea1-2); Inserm ex-U794: N Chateigner (Egea1-2); Grenoble: J Quentin (Egea1-2).

The authors thank all those who participated to the setting of the study and on the various aspects of the examinations involved: interviewers, technicians for lung function testing and skin prick tests, blood sampling, IgE determinations, coders, those involved in quality control, data and sample management and all those who supervised the study in all centers. The authors are grateful to the three CIC-Inserm of Necker, Grenoble and Marseille who supported the study and in which participants were examined. They are also grateful to the biobanks in Lille (CICInserm), and at Annemasse (Etablissement français du sang) where biological samples are stored. 
They are indebted to all the individuals who participated, without whom the study would not have been possible.

\section{Funding}

Research was funded in part by the National Hospital program of clinical research (PHRCnational 2012, EvAdA), ANR-CES-2009, Region Nord Pas-de-Calais, Merck Sharp \& Dohme (MSD), the GA2LEN project, Global Allergy and Asthma European Network, the Fonds AGIR

pour les maladies chroniques, the People Programme (Marie Curie Actions) of the European Union's Seventh Framework Programme (FP7/2007-2013) under REA grant agreement $n$. PCOFUND-GA-2013-609102 through the PRESTIGE programme coordinated by Campus France, and by University of Versailles Saint-Quentin-en-Yvelines EDSP doctoral grant. 


\section{References}

1. Vos T, Allen C, Arora M, Barber RM, Bhutta ZA, Brown A, Carter A, Casey DC, Charlson FJ, Chen AZ, Coggeshall M, Cornaby L, Dandona L, Dicker DJ, Dilegge T, Erskine HE, Ferrari AJ, Fitzmaurice C, Fleming T, Forouzanfar MH, Fullman N, Gething PW, Goldberg EM, Graetz N, Haagsma JA, Johnson CO, Kassebaum NJ, Kawashima T, Kemmer L, Khalil IA, et al. Global, regional, and national incidence, prevalence, and years lived with disability for 310 diseases and injuries, 1990-2015: a systematic analysis for the Global Burden of Disease Study 2015. Lancet 2016; 388: 1545-1602.

2. Beasley R, Semprini A ME. Risk factors for asthma: is prevention possible? Lancet 2015. p. 12;386(9998).

3. Gauthier M, Ray A, Wenzel SE. Evolving concepts of asthma. Am. J. Respir. Crit. Care Med. 2015; 192: 660-668.

4. Wenzel SE. Asthma phenotypes: the evolution from clinical to molecular approaches. Nat. Med. Nature Publishing Group; 2012; 18: 716-725.

5. Fajt ML, Wenzel SE. Asthma phenotypes and the use of biologic medications in asthma and allergic disease: The next steps toward personalized care. J. Allergy Clin. Immunol. Elsevier Ltd; 2015; 135: 299-310.

6. Czerska M, Zieliński M, Gromadzińska J. Isoprostanes - A novel major group of oxidative stress markers. Int. J. Occup. Med. Environ. Health 2016; 29: 179-190.

7. Ricciardolo FLM, Sterk PJ, Gaston B, Folkerts G. Nitric Oxide in Health and Disease of the Respiratory System. Physiol Rev 2004; 84: 731-765.

8. Rahman I, Biswas SK, Kode A. Oxidant and antioxidant balance in the airways and airway diseases. Eur. J. Pharmacol. 2006; 533: 222-239.

9. Malling TH, Sigsgaard T, Andersen HR, Deguchi Y, Brandslund I, Skadhauge L, Thomsen G, Baelum J, Sherson D, Omland Ø. Differences in Associations Between Markers of Antioxidative Defense and Asthma Are Sex Specific. Gend. Med. 2010; 7 : $115-124$.

10. Ghosh S, Willard B, Comhair S a a, Dibello P, Xu W, Shiva S, Aulak KS, Kinter M, Erzurum SC. Disulfide bond as a switch for copper-zinc superoxide dismutase activity in asthma. Antioxid. Redox Signal. 2013; 18: 412-423.

11. Mittal M, Siddiqui MR, Tran K, Reddy SP MA. Reactive Oxygen Species in Inflammation and Tissue Injury. Antioxid Redox Signal 2014. p. 20(7):1126-67.

12. Aldakheel FM, Thomas PS, Bourke JE, Matheson MC, Dharmage SC LA. Relationships between adult asthma and oxidative stress markers and $\mathrm{pH}$ in exhaled breath condensate: a 
systematic review. Allergy 2016.

13. Mak JCWC-YM. Systemic oxidative and antioxidative status in Chinese patients with asthma. Curr Opin Pulm Med. 2004. p. 114(2):260-411.

14. Al-Afaleg NO, Al-Senaidy A E-AA. Oxidative stress and antioxidant status in Saudi asthmatic patients. Clin. Biochem. 2011. p. 44(8-9):612-7.

15. Ahmad A, Shameem M, Husain Q. Relation of oxidant-antioxidant imbalance with disease progression in patients with asthma. Ann. Thorac. Med. 2012; 7: 226-232.

16. Ochs-Balcom HM, Grant BJB, Muti P, Sempos CT, Freudenheim JL, Browne RW, Trevisan M, Iacoviello L, Cassano PA, Schü Nemann HJ. Original Contribution Oxidative Stress and Pulmonary Function in the General Population. Am. J. Epidemiol. 2005; 162: $1137-1145$.

17. Rebholz CM, Wu T, Hamm LL, Arora R, Khan IE, Liu Y, Chen C-S, Mills KT, Rogers S, Kleinpeter MA, Simon EE, Chen J. The association of plasma fluorescent oxidation products and chronic kidney disease: a case-control study. Am. J. Nephrol. 2012; 36: 297304.

18. Wu T, Willett WC, Rifai N, Rimm EB. Plasma fluorescent oxidation products as potential markers of oxidative stress for epidemiologic studies. Am. J. Epidemiol. 2007; 166: 552560 .

19. Wu T, Rifai N, Walter C. Willett and Eric B. Rimm. Plasma Fluorescent Oxidation Products: Independent Predictors of Coronary Heart Disease in Men. Am. J. Epidemiol. 2007. p. 166(5):544-51.

20. Kauffmann F, Dizier M. EGEA_design issues. Clin. Exp. Allergy 1995. p. 19-22.

21. Kauffmann F, Dizier MH, Pin I, Paty E, Gormand F, Vervloet D, Bousquet J, Neukirch F, Annesi I, Oryszczyn MP, Lathrop M, Demenais F, Lockhart A FJ. Epidemiologic Study of the Genetics and Environment of Asthma, Bronchial Hyperresponsiveness, and Atopy. Am J Respir Crit Care Med 1997; 156: s123-s129.

22. Nadif R, Bouzigon E, Le Moual N, Siroux V. EGEA Collection: a biobank devoted to asthma and asthma-related phenotypes. Open J. Bioresour. 2017; 322: 891-921.

23. Burney PGJ, Luczynska C, Chinn S, Jarvis D. The European Community Respiratory Health Survey. Eur. Respir. J. 1994; : 954-960.

24. Siroux V, Boudier A, Bousquet J, Bresson JL, Cracowski JL, Ferran J, Gormand F, Just J, Le Moual N, Morange S, Nadif R, Oryszczyn MP, Pison C, Scheinmann P, Varraso R, Vervloet D, Pin I KFES on the G and E of A. Phenotypic determinants of uncontrolled asthma. J Allergy Clin Immunol 2009. p. 124(4):681-7.

25. Siroux V, Boudier A, Dolgopoloff M, Chanoine S, Bousquet J, Gormand F, Just J, Le Moual N, Nadif R, Pison C, Varraso R, Matran R, Pin I. Forced midexpiratory flow between $25 \%$ and $75 \%$ of forced vital capacity is associated with long-term persistence of 
asthma and poor asthma outcomes. J. Allergy Clin. Immunol. 2016; 137: 1709-1716e6.

26. Nadif R, Siroux V, Boudier A, Le Moual N, Just J, Gormand F, Pison C. Blood granulocyte patterns as predictors of asthma phenotypes in adults from the EGEA study. Eur Respir J 2016; 48: 976-978.

27. Zerimech F, Huyvaert H, Matran R, Nadif R. Usefulness of a new dialysis device adapted to small volume of red blood cells and its interest in epidemiology. Clin. Biochem. 2011; 44: 739-741.

28. Nadif R, Jedlicka A, Mintz M, Bertrand J-P, Kleeberger S, Kauffmann F. Effect of TNF and LTA polymorphisms on biological markers of response to oxidative stimuli in coal miners: a model of gene-environment interaction. Tumour necrosis factor and lymphotoxin alpha. J. Med. Genet. 2003; 40: 96-103.

29. Dumas O, Matran R, Zerimech F, Decoster B, Huyvaert H, Ahmed I, Le Moual N, Nadif R. Occupational exposures and fluorescent oxidation products in 723 adults of the EGEA study. Eur Respir J 2015; 4: 1-4.

30. Schulte PA. Contribution of Biological Markers to Occupational Health. Am. J. Ind. Med. 1998; 446: 435-446.

31. Schünemann HJ, Muti P, Freudenheim JL, Armstrong D, Browne R, Klocke RA, Trevisan M. Oxidative Stress and Lung Function. Am. J. Epidemiol. 1997; 146: 939-948.

32. Janssen LJ. Isoprostanes: an overview and putative roles in pulmonary pathophysiology. Am. J. Physiol. Cell. Mol. Physiol. 2001; 280: L1067-L1082.

33. Nadeem A, Chhabra SK, Masood A RH. Increased oxidative stress and altered levels of antioxidants in asthma. $J$ Allergy Clin Immunol 2003; 111: 72-78.

34. Yang L, Huang M, Huang C, Wang T. The Association between Adult Asthma and Superoxide Dismutase and Catalase Gene Activity. Int. Arch. Allergy Immunol. 2011; 156: 373-380.

35. Montuschi P, Corradi M, Ciabattoni G, Nightingale J, Kharitonov SA BP. Increased 8Isoprostane, a Marker of Oxidative Stress, in Exhaled Condensate of Asthma Patients. Am J Respir Crit Care Med 1999. p. 160(1):216-20.

36. Zhao JJ, Shimizu Y, Dobashi K, Kawata T, Ono A, Yanagitani N, Kaira K, Utsugi M, Hisada T, Ishizuka T, Mori M. The Relationship Between Oxidative Stress and Acid Stress in Adult Patients With Mild Asthma. J Investig Allergol Clin Immunol 2008; 18: 41-45.

37. Zuo L, Pannell BK, Liu Z. Characterization and redox mechanism of asthma in the elderly. Oncotarget 2016; 7.

38. Dumas O, Le Moual N. Do chronic workplace irritant exposures cause asthma? Curr. Opin. Allergy Clin. Immunol. 2016; 16: 75-85.

39. Matulonga B, Rava M, Siroux V, Bernard A, Dumas O, Pin I, Zock JP, Nadif R, Leynaert 
B, Le Moual N. Women using bleach for home cleaning are at increased risk of nonallergic asthma. Respir. Med. Elsevier Ltd; 2016; 117: 264-271.

40. Folletti I, Siracusa A, Paolocci G. Update on asthma and cleaning agents. Curr. Opin. Allergy Clin. Immunol. 2017; 17: 90-95. 


\section{Figure legends}

Figure 1: Levels of biomarkers of response related to oxidative stress according to ever asthma.

Boxplots show the median (bar), the first and third quartiles (box), the $1^{\text {st }}$ and $99^{\text {th }}$ percentiles (fences) and the minimum and maximum (stars) of the biomarkers level for each asthma status. The y-axis to the left represents the raw biomarker concentration and the y-axis to the right represents the $\log 10$ concentration. Catalase was not log-transformed.

SOD: Superoxide dismutase; GPX: Glutathione peroxidase; GM: Geometric mean; Q1-Q3: first and third quartiles; SD: standard deviation.

Figure 2: Levels of biomarkers of damage related to oxidative stress according to ever asthma.

Boxplots show the median (bar), the first and third quartiles (box), the $1^{\text {st }}$ and $99^{\text {th }}$ percentiles (fences) and the minimum and maximum (stars) of the biomarkers level for each asthma status. Except for the 8 -isoprostanes where the fences represent the $10^{\text {th }}$ and $90^{\text {th }}$ percentiles. The $y$-axis to the left represents the raw biomarker concentration and the y-axis to the right represents the $\log 10$ concentration.

F1OPs: Fluorescent Oxidation Products; GM: Geometric mean; Q1-Q3: first and third quartiles; SD: standard deviation. 
Table 1: Description of participant characteristics, according to ever asthma (n=1388).

\begin{tabular}{|c|c|c|c|c|}
\hline & All participants & Without ever asthma & With ever asthma & \\
\hline & $\mathrm{n}=1388$ & $\mathrm{n}=774$ & $\mathrm{n}=614$ & $\mathrm{p}^{\dagger}$ \\
\hline Sex, women, \% & 51.1 & 54.4 & 47.1 & 0.01 \\
\hline Age, mean (SD) & $43.1(16.5)$ & $46.2(15.9)$ & $39.1(16.3)$ & $<0.0001$ \\
\hline $\begin{array}{l}\text { Body Mass Index, } \mathrm{kg} / \mathrm{m}^{2}, \% \\
\quad<20 \\
\quad[20-25[ \\
\quad[25-30[ \\
\quad \geq 30\end{array}$ & $\begin{array}{l}\mathrm{n}=1365 \\
10.6 \\
51.6 \\
27.8 \\
10.0\end{array}$ & $\begin{array}{l}\mathrm{n}=761 \\
9.33 \\
50.5 \\
30.1 \\
10.1\end{array}$ & $\begin{array}{l}\mathrm{n}=604 \\
12.2 \\
53.0 \\
24.8 \\
9.93\end{array}$ & 0.09 \\
\hline $\begin{array}{l}\text { Smoking status, \% } \\
\text { Non smoker } \\
\text { Ex-smoker } \\
\text { Current smoker }\end{array}$ & $\begin{array}{l}50.1 \\
27.4 \\
22.5\end{array}$ & $\begin{array}{l}50.1 \\
29.2 \\
20.7\end{array}$ & $\begin{array}{l}50.2 \\
25.1 \\
24.8\end{array}$ & 0.10 \\
\hline $\begin{array}{l}\text { Age of asthma onset, } \% \\
<4 \text { years } \\
{[4-16[\text { years }} \\
\geq 16 \text { years }\end{array}$ & $\begin{array}{l}\mathrm{n}=573 \\
30.5 \\
35.1 \\
34.4\end{array}$ & - & $\begin{array}{l}\mathrm{n}=573 \\
30.5 \\
35.1 \\
34.4\end{array}$ & \\
\hline Current asthma, $\%$ & $\begin{array}{l}\mathrm{n}=572 \\
88.8\end{array}$ & - & $\begin{array}{l}\mathrm{n}=572 \\
88.8\end{array}$ & \\
\hline $\begin{array}{l}\text { Asthma control, \% } \\
\text { Controlled } \\
\text { Partly controlled } \\
\text { Uncontrolled }\end{array}$ & $\begin{array}{l}\mathrm{n}=537 \\
57.9 \\
31.5 \\
10.6\end{array}$ & - & $\begin{array}{l}\mathrm{n}=537 \\
57.9 \\
31.5 \\
10.6\end{array}$ & \\
\hline Asthma attacks (last 12 months), $\%$ & $\begin{array}{l}\mathrm{n}=611 \\
38.1\end{array}$ & & $\begin{array}{l}\mathrm{n}=611 \\
38.1\end{array}$ & \\
\hline Exacerbation (last 12 months), $\%$ & $\begin{array}{l}\mathrm{n}=573 \\
13.6\end{array}$ & - & $\begin{array}{l}\mathrm{n}=573 \\
13.6\end{array}$ & \\
\hline $\begin{array}{l}\text { Respiratory symptoms } \\
\text { (last } 12 \text { months), \% }\end{array}$ & $\begin{array}{l}\mathrm{n}=1377 \\
54.6\end{array}$ & $\begin{array}{l}\mathrm{n}=768 \\
36.2\end{array}$ & $\begin{array}{l}\mathrm{n}=609 \\
77.8\end{array}$ & $<0.0001$ \\
\hline $\begin{array}{l}\text { Use of any asthma treatments } \\
\text { (last } 12 \text { months), \% }\end{array}$ & $\begin{array}{l}\mathrm{n}=1388 \\
34.8\end{array}$ & $\begin{array}{l}\mathrm{n}=774 \\
10.3\end{array}$ & $\begin{array}{l}\mathrm{n}=614 \\
65.6\end{array}$ & $<0.0001$ \\
\hline Use of ICS (last 12 months), $\%$ & $\begin{array}{l}\mathrm{n}=1381 \\
19.6\end{array}$ & $\begin{array}{l}\mathrm{n}=772 \\
3.24\end{array}$ & $\begin{array}{l}n=609 \\
40.4\end{array}$ & $<0.0001$ \\
\hline FEV1 \% predicted, mean (SD) & $\begin{array}{l}\mathrm{n}=1360 \\
102(18.0)\end{array}$ & $\begin{array}{l}\mathrm{n}=757 \\
107(16.5)\end{array}$ & $\begin{array}{l}\mathrm{n}=603 \\
96.9(18.4)\end{array}$ & $<0.0001$ \\
\hline FEV1 $<80 \%$ predicted, $\%$ & $\begin{array}{l}\mathrm{n}=1360 \\
9.7\end{array}$ & $\begin{array}{l}\mathrm{n}=757 \\
5.42\end{array}$ & $\begin{array}{l}\mathrm{n}=603 \\
15.1\end{array}$ & $<0.0001$ \\
\hline $\begin{array}{l}\text { Methacholine challenge } \\
\text { PD } 20 \leq 4 \mathrm{mg}, \%\end{array}$ & $\begin{array}{l}n=851 \\
44.3\end{array}$ & $\begin{array}{l}n=487 \\
26.9\end{array}$ & $\begin{array}{l}n=364 \\
67.6\end{array}$ & $<0.0001$ \\
\hline Skin prick test positivity**, $\%$ & $\begin{array}{l}\mathrm{n}=1281 \\
56.3\end{array}$ & $\begin{array}{l}\mathrm{n}=716 \\
38.5\end{array}$ & $\begin{array}{l}\mathrm{n}=565 \\
78.8\end{array}$ & $<0.0001$ \\
\hline $\begin{array}{l}\text { Total IgE } \\
\quad \geq 100 \mathrm{IU} / \mathrm{mL}, \%\end{array}$ & $\begin{array}{l}n=1383 \\
43.0\end{array}$ & $\begin{array}{l}\mathrm{n}=772 \\
29.5\end{array}$ & $\begin{array}{l}n=611 \\
60.1\end{array}$ & $<0.0001$ \\
\hline $\begin{array}{l}\text { Eosinophils count } \\
\quad \geq 250 \mathrm{cell} / \mathrm{mm}^{3}, \%\end{array}$ & 26.9 & 17.2 & 39.2 & $<0.0001$ \\
\hline $\begin{array}{l}\text { Neutrophils count } \\
\quad \geq 5000 \text { cells } / \mathrm{mm}^{3}, \%\end{array}$ & 20.0 & 19.2 & 21.0 & 0.42 \\
\hline
\end{tabular}

ICS: Inhaled corticosteroids only or in combination with long actin B2-agonist; FEV1: Forced expiratory volume in one second; IgE: Immunoglobulin E; § Asthma treatments were defined by the use of inhaled and/or oral medicines in the past twelve months because of breathing problems.; ** Skin Prick Test positivity (SPT + ) was defined by a mean wheal diameter $\geq 3 \mathrm{~mm}$ than the negative control for at least one of 12 aeroallergens; PD20: provocative dose causing a 20\% fall in FEV ; \#Methacholine challenge test was not performed if baseline FEV1 $<80 \%$ predicted; $\dagger$ p-value of $\chi^{2}$ test for categorical variables and Student test for quantitative variables. 
Table 2: Associations between biomarkers of damage related to oxidative stress and various asthma outcomes.

\begin{tabular}{|c|c|c|c|c|c|c|}
\hline & \multicolumn{3}{|c|}{ 8-isoprostanes (pg/mL) } & \multicolumn{3}{|c|}{ Fluorescent oxidation products (RFU/mL) } \\
\hline & $\mathrm{n}$ & OR $(95 \% \mathrm{CI})^{*}$ & $\mathrm{OR}_{\text {adjusted }}(95 \% \mathrm{CI})^{*}$ & $\mathrm{n}$ & OR $(95 \% \mathrm{CI})^{*}$ & $\mathrm{OR}_{\text {adjusted }}(95 \% \mathrm{CI})^{*}$ \\
\hline $\begin{array}{l}\text { Asthma ever } \\
\text { (vs never asthma) }\end{array}$ & 688 & $1.40(1.17 ; 1.67)$ & $1.28(1.06 ; 1.55)$ & 1325 & $0.84(0.73 ; 0.96)$ & $0.98(0.86 ; 1.13)$ \\
\hline \multicolumn{7}{|l|}{$\begin{array}{l}\text { Among participants with } \\
\text { ever asthma }\end{array}$} \\
\hline $\begin{array}{l}\text { Current asthma } \\
\text { ( } v \text { s without current asthma) }\end{array}$ & 295 & $0.65(0.38 ; 1.13)$ & $0.69(0.40 ; 1.18)$ & 547 & $1.44(0.97 ; 2.16)$ & $1.38(0.92 ; 2.06)$ \\
\hline $\begin{array}{l}\text { Poor asthma control** } \\
\text { (vs controlled asthma) }\end{array}$ & 282 & $0.82(0.59 ; 1.15)$ & $0.86(0.61 ; 1.22)$ & 514 & $1.40(1.11 ; 1.77)$ & $1.30(1.02 ; 1.66)$ \\
\hline $\begin{array}{l}\text { Asthma attacks in the } \\
\text { last } 12 \text { months }\end{array}$ & 315 & $0.80(0.58 ; 1.10)$ & $0.80(0.57 ; 1.12)$ & 584 & $1.27(1.04 ; 1.55)$ & $1.33(1.07 ; 1.65)$ \\
\hline $\begin{array}{l}\text { Respiratory symptoms in } \\
\text { the last } 12 \text { months }\end{array}$ & 311 & $0.73(0.35 ; 1.10)$ & $0.76(0.39 ; 1.13)$ & 582 & $1.17(0.87 ; 1.46)$ & $1.11(0.81 ; 1.41)$ \\
\hline $\begin{array}{l}\text { Any asthma treatments in } \\
\text { the last } 12 \text { months }{ }^{\S}\end{array}$ & 315 & $0.77(0.45 ; 1.09)$ & $0.80(0.47 ; 1.13)$ & 587 & $1.34(1.12 ; 1.56)$ & $1.29(1.05 ; 1.52)$ \\
\hline $\begin{array}{l}\text { Use of ICS in last } 12 \\
\text { months }\end{array}$ & 313 & $0.72(0.51 ; 1.00)$ & $0.80(0.57 ; 1.11)$ & 582 & $1.45(1.19 ; 1.77)$ & $1.30(1.05 ; 1.60)$ \\
\hline $\mathrm{FEV}_{1}<80 \%$ predicted $* *$ & 314 & $0.85(0.52 ; 1.39)$ & $1.01(0.64 ; 1.60)$ & 579 & $1.63(1.28 ; 2.07)$ & $1.34(1.04 ; 1.74)$ \\
\hline $\begin{array}{l}\text { Methacholine challenge } \\
\text { PD20 } \leq 4 \mathrm{mg}^{* * \#}\end{array}$ & 193 & $0.92(0.54 ; 1.30)$ & $0.84(0.42 ; 1.26)$ & 354 & $0.97(0.68 ; 1.26)$ & $0.97(0.65 ; 1.28)$ \\
\hline
\end{tabular}


Table 3: Associations between biomarkers of damage related to oxidative stress, markers of allergy and markers of inflammation in participants with ever asthma.

\begin{tabular}{|c|c|c|c|c|c|c|}
\hline & \multicolumn{3}{|c|}{ 8-isoprostanes (pg/mL) } & \multicolumn{3}{|c|}{ Fluorescent oxidation products (RFU/mL) } \\
\hline & $\mathrm{n}$ & OR $(95 \% \mathrm{CI})^{*}$ & $\mathrm{OR}_{\text {adjusted }}(95 \% \mathrm{CI})^{*}$ & $\mathrm{n}$ & OR $(95 \% \mathrm{CI})^{*}$ & $\mathrm{OR}_{\text {adjusted }}(95 \% \mathrm{CI})^{*}$ \\
\hline \multicolumn{7}{|l|}{ Markers of allergy } \\
\hline $\begin{array}{l}\text { Total IgE } \\
\geq 100 \mathrm{IU} / \mathrm{mL}\end{array}$ & 314 & $0.98(0.72 ; 1.34)$ & $0.85(0.61 ; 1.18)$ & 584 & $0.99(0.82 ; 1.21)$ & $1.17(0.93 ; 1.47)$ \\
\hline Positive SPT & 297 & $0.92(0.62 ; 1.37)$ & $0.70(0.47 ; 1.05)$ & 546 & $0.86(0.68 ; 1.08)$ & $1.19(0.90 ; 1.57)$ \\
\hline \multicolumn{7}{|l|}{$\begin{array}{l}\text { Markers of } \\
\text { inflammation }\end{array}$} \\
\hline $\begin{array}{l}\text { Neutrophils** } \\
\geq 5000 \text { cells } / \mathbf{m m}^{3}\end{array}$ & 315 & $0.88(0.62 ; 1.26)$ & $0.94(0.65 ; 1.36)$ & 587 & $1.38(1.11 ; 1.72)$ & $1.34(1.06 ; 1.70)$ \\
\hline $\begin{array}{l}\text { Eosinophils** } \\
\geq 250 \text { cells } / \mathbf{m m}^{3}\end{array}$ & 315 & $0.87(0.63 ; 1.19)$ & $0.84(0.60 ; 1.16)$ & 587 & $0.94(0.78 ; 1.13)$ & $1.02(0.84 ; 1.25)$ \\
\hline
\end{tabular}

* OR expressed for an increase corresponding to the value of the interquartile range (distance between the $25^{\text {th }}$ and $75^{\text {th }}$ percentile) of each biological markers; adjusted for age, sex and smoking status; **Results were unchanged when restricting analyses to participants with current asthma; SPT: skin prick test; IgE: Immunoglobulin E. 


\section{ONLINE SUPPLEMENTARY MATERIALS}

\section{Oxidative stress biomarkers and asthma characteristics in adults of the EGEA study}

Miora Andrianjafimasy ${ }^{1,2}$, Farid Zerimech ${ }^{3,4}$, Zeina Akiki ${ }^{1,2}$, Helene Huyvaert ${ }^{3}$, Nicole Le Moual $^{1,2}$, Valérie Siroux ${ }^{5}$, Régis Matran ${ }^{6,7}$, Orianne Dumas ${ }^{1,2}$, Rachel Nadif ${ }^{1,2}$

\section{Affiliations:}

1. INSERM, U1168, Aging and chronic diseases. Epidemiological and Public health approaches, F-94807 Villejuif, France

2. Univ Versailles St-Quentin-en-Yvelines, UMR-S 1168, F-78180 Montigny-le-Bretonneux, France

3. CHU Lille, Service de Biochimie et Biologie moléculaire, F-59000 Lille, France

4. Université de Lille, EA4483, IMPECS, Institut Pasteur de Lille, F-59000 Lille, France

5. Institute for Advanced Biosciences, Centre de recherche UGA-Inserm U1209-CNRS UMR 5309, équipe d'épidémiologie environnementale, Site Santé, Allée des Alpes, F-38700 La Tronche, France

6. CHRU de Lille, France, F-59000 Lille, France

7. Univ Lille Nord de France, F-59000 Lille, France

\section{Corresponding author:}

Miora Andrianjafimasy, INSERM, U 1168, Aging and chronic diseases.

Epidemiological and Public health approaches, F-94807 Villejuif, France

Phone number: 33 (0) 145595073

Email : miora.andrianjafimasy@inserm.fr 


\section{Methods}

\section{Asthma outcomes}

Asthma control has been assessed over 3 month period, using responses to EGEA2 survey questions to approximate the Global Initiative for Asthma 2015 definition as closely as possible and as previously used [1]. Participants were defined as having controlled, partly controlled, and uncontrolled asthma if they had none, 1 to 2, or 3 to 4 of the following criteria, respectively: frequent daytime symptoms (defined by $\geq 1$ asthma attacks or $\geq 1$ episodes of trouble breathing per week in the past 3 months), any nighttime symptoms (defined as waking because of asthma or an attack of shortness of breath in the last 3 months), frequent use of reliever medication (defined, on average, as more than twice a week in the past 3 months), and any activity limitation (defined by the following answers: "totally limited," "extremely limited," "very limited," "moderate limitation," and "some limitation" to the question " Overall, among all the activities that you have done during the last two weeks, how limited have you been by your asthma?' ').

\section{Lung function, allergic and inflammatory characteristics}

A lung function test with spirometry and methacholine challenge was performed using standardized protocol with similar equipment across centers according to the American Thoracic Society / European Respiratory Society guidelines [2]. Forced expiratory volume in one second $\left(\mathrm{FEV}_{1}\right)$ percent predicted value was based on Quanjer et al. reference equations [3]. For participants with a FEV1 $\geq 80 \%$ of the predicted value, a methacholine bronchial challenge test was performed (maximum dose $4 \mathrm{mg}$ ) using a Biomedin spirometer (Biomedin 
Srl, Padua, Italy) in all centers, except in Lyon, where a Pneumotach Jaeger spirometer (Jaeger) was used [4].

Allergic sensitization was defined by a positive skin prick test (SPT + ) with a mean wheal diameter $\geq 3 \mathrm{~mm}$ than the negative control for at least one of 12 aeroallergens (indoor: cat, Dermatophagoides pteronyssinus, Blattela germanica, outdoor: olive, birch, Parieteria judaica, timothy grass, Cupressus and ragweed pollen, and molds: Aspergillus, Cladosporium herbarum, Alternaria tenuis). Subjects were classified as sensitized if they have one or more $\mathrm{SPT}+[5]$.

Total Immunoglobulin E (IgE) determination was assessed by UniCAP system (Pharmacia $\left.{ }^{\circledR}\right)$ from blood samples in a centralized laboratory, and expressed in international units (IU) per milliliter.

Blood inflammatory patterns were defined from white blood cell (WBC) counts according to eosinophil (EOS) and neutrophil (NEU) counts cut-off points previously described[6, 7]. Briefly, the cut-off point for eosinophils $\left(250 \mathrm{EOS} / \mathrm{mm}^{3}\right)$ is the one commonly used in epidemiology, and corresponded to the 75 th percentile in the 1356 adults at the EGEA1 study. A cut-off point of $5000 \mathrm{NEU} / \mathrm{mm}^{3}$ was chosen that corresponded to the 75 th percentile of the distribution.

\section{Determination of biomarkers of oxidative stress}

\section{Blood collection}


Blood samples were collected into $5 \mathrm{~mL}$ Vacutainer tubes containing heparinate as an anticoagulant (Becton Dickinson, USA). On the same day, corresponding plasma and glycerolized red blood cells (RBCs) were prepared and stored at $-80^{\circ} \mathrm{C}$. Briefly, $38 \%$

wt/vol glycerol was added progressively to an equal volume of RBCs to obtain a final concentration of $19 \%$ glycerol. Glycerolized RBCs aliquots were stored from 2 to 10 years until analysis. Immediately after thawing at room temperature, RBCs were diluted by addition of ice-cold distilled water $(1: 1)$; the resulting hemolysate was centrifuged at $3000 \times \mathrm{g}$ for 10 min at $+4^{\circ} \mathrm{C}$ to remove unbroken cells and large cell debris. Dialysis of the supernatant was performed on D-Tube $96^{\mathrm{TM}}$ DialyzerMini device (Novagen,Madison,WI,USA). Each kit contains a floating rack allowing dialysis up to 96 samples $(10-250 \mu 1)$ through a dual membrane with molecular weight cutoffs of $6-8 \mathrm{kDa}$ or $12-14 \mathrm{kDa}$. The $6-8 \mathrm{kDa}$ cutoff was chosen to remove glycerol. $170 \mu \mathrm{L}$ of supernatant was carefully added to D-Tube $96^{\mathrm{TM}}$ previously prehydrated for $10 \mathrm{~min}$ with distilled water. The floating rack was placed in beaker containing 2 L of 0.1 Msodiumphosphate buffer ( $\mathrm{pH}$ 7.4) and a stir bar [8].

\section{Measurement of antioxidant enzyme activities}

All assays were carried out at the Laboratory of Biochemistry Molecular Biology of CHRU de Lille according to validated and standardized procedures. Catalase activity was measured according to the method by Aebi [8,9]. Glutathione peroxidase (GPx) and superoxide dismutase (SOD) activities were estimated using commercial available kits (Randox Laboratories, Mauguio, France) according to the method by Paglia and Valentine $[8,10]$ and McCord and Fridovich $[8,11]$ respectively.

Total hemoglobin $(\mathrm{Hb})$ concentration was measured by the cyanmethemoglobin method $[8$, 12]. Activities were expressed as $\mathrm{U} / \mathrm{g} \mathrm{Hb}(\mathrm{SOD}, \mathrm{GPx})$ or $\mathrm{k} / \mathrm{g} \mathrm{Hb}$ (catalase). All samples were 
analyzed in duplicate or triplicate and analytical intra-run imprecisions (CV) were below $10 \%$.

\section{Results}

\section{Description of medication data}

Regarding medication for asthma, $59.6 \%$ of the participants did not take any medication in the last twelve months. Among those who reported medication use in the last twelve months, $39.2 \%$ reported ICS use only and $60.8 \%$ reported ICS use in combination with long acting B2-agonists (LABA). In the last three months, 23.3\% reported regular use of ICS (ICS or ICS+LABA), and $11.6 \%$ reported irregular use of ICS (ICS or ICS+LABA). Median [minmax] main daily ICS dose over the past twelve month was of 250 [50-500] $\mu \mathrm{g}$ of beclomethasone equivalent.

\section{Associations between FIOPs level and ICS use}

We performed supplementary analyses between medication expressed in three classes (no use, ICS only and ICS in combination with LABA) and FlOPs level, and found a positive and significant association: geometric mean [Q1; Q3] of F1OPs level was 88.9 [76.7; 100], 93.2 [81.5; 103] and 97.1 $[79.7 ; 109] \mathrm{RFU} / \mathrm{mL}$ in no use, ICS only and ICS+LABA respectively, P for trend $=0.01$. In addition, we studied the association between FlOPs and ICS dose $(\mu \mathrm{g})$ over the past twelve months and the ICS use in the last three months expressed as no use/ irregular use / regular use) and found that FlOPs level was positively associated with the ICS use 
(geometric mean [Q1; Q3] of FlOPs level was 88.8 [76.5; 100], 90.9 [76.6; 103] and 100 [83.3; 110] RFU/mL in the class of no use, irregular use and regular use respectively $(p<0.001))$. We did not find a correlation between FlOPs level and ICS dose. 


\section{References}

1. Siroux V, Boudier A, Dolgopoloff M, Chanoine S, Bousquet J, Gormand F, Just J, Le Moual N, Nadif R, Pison C, Varraso R, Matran R, Pin I. Forced midexpiratory flow between $25 \%$ and $75 \%$ of forced vital capacity is associated with long-term persistence of asthma and poor asthma outcomes. J. Allergy Clin. Immunol. 2016; 137: 1709$1716 \mathrm{e} 6$.

2. Miller MR, Hankinson J, Brusasco V, Burgos F, Casaburi R, Coates A, Crapo R, Enright P, van der Grinten CPM, Gustafsson P, Jensen R, Johnson DC, MacIntrye N, McKay R, Navajas D, Pedersen OF, Pellegrino R, Viegi G, Wagner J. Standardisation of spirometry. Eur. Respir. J. 2005; 26: 319-338.

3. Quanjer PH, Tammeling GJ, Cotes JE, Pedersen OF, Peslin R, Yernault J-C. Lung volumes and forced ventilatory flows. Eur. Respir. J. 1993.

4. Siroux V, Pin I, Oryszczyn MP, Le Moual N, Kauffmann F. Relationships of active smoking to asthma and asthma severity in the EGEA study. Eur. Respir. J. 2000; 15: $470-477$.

5. Burte E, Bousquet J. Characterization of Rhinitis According to the Asthma Status in Adults Using an Unsupervised Approach in the EGEA Study. PLoS One 2015; 10: 118.

6. Nadif R, Siroux V, Oryszczyn MP, Ravault C, Pison C, Pin I, Kauffmann F, Epidemiological study on the G, Environment of A. Heterogeneity of asthma according to blood inflammatory patterns. Thorax 2009; 64: 374-380.

7. Nadif R, Siroux V, Boudier A, Le Moual N, Just J, Gormand F, Pison C. Blood granulocyte patterns as predictors of asthma phenotypes in adults from the EGEA study. Eur Respir J 2016; 48: 976-978.

8. Zerimech F, Huyvaert H, Matran R, Nadif R. Usefulness of a new dialysis device adapted to small volume of red blood cells and its interest in epidemiology. Clin. Biochem. 2011; 44: 739-741.

9. Aebi H. Catalase. In: Bergmeyer HU, editor. Methods Enzym. Anal. New York; 1974. p. 673-684.

10. Paglia DE, Valentine WN. Studies on the quantitative and qualitative characterization of erythrocyte glutathione peroxidase. J. Lab. Clin. Med. 1967; 70: 158-169.

11. Mc Cord JM, Fridovic I. Superoxide dismutase. An enzymic function for erythrocuprein. J. Biol. Chem. 1969; 244: 6049-6055.

12. Zwart A, van Assendelft OW, Bull BS, England JM, Lewis SM, Zijlstra WG. Recommendations for reference method for haemoglobinometry in human blood (ICSH standard 1995) and specifications for international haemiglobinocyanide standard (4th edition). J. Clin. Pathol. 1996; 49: 271-274. 
Figure legends:

Figure E1: Flow chart of the population studied

Figure E2: Boxplots of plasma Fluorescent oxidation products level, in non-asthmatic participants according to smoking status, number of cigarette packs per year in current and ex-smokers and tobacco daily consumption in current smokers.

FlOPS: Fluorescent Oxidation Products; Boxplots show the median (bar), the first and third quartiles (box), the first and 99th percentiles and the minimum and maximum (fences) for each category. Except in non-smokers, ex-smokers, smokers and in the first category $(<10$ packs/year) of current and ex-smokers where the fences represent the 1st and 99th percentiles and the stars represent the minimum and maximum. 
Table E1: Characteristics of the participants included or non-selected in the analyses.

\begin{tabular}{|c|c|c|c|c|c|c|c|}
\hline & \multicolumn{2}{|c|}{$\begin{array}{l}\text { All participants } \\
\qquad \mathrm{n}=1571\end{array}$} & \multicolumn{2}{|c|}{$\begin{array}{l}\text { Participants included } \\
\qquad \mathrm{n}=1388\end{array}$} & \multicolumn{2}{|c|}{$\begin{array}{l}\text { Participants non selected } \\
\qquad \mathrm{n}=183\end{array}$} & \multirow[b]{2}{*}{$\mathrm{p}^{\dagger}$} \\
\hline & $\mathrm{n}$ & Percent, mean (SD) & $\mathrm{n}$ & Percent, mean (SD) & $\mathrm{n}$ & Percent, mean (SD) & \\
\hline Sex, women & 1571 & 50.6 & 1388 & 51.2 & 183 & 46.5 & 0.23 \\
\hline Age, mean (SD) & 1571 & $42.8(16.5)$ & 1388 & $43.0(16.5)$ & 183 & $40.7(16.9)$ & 0.08 \\
\hline $\begin{array}{l}\text { Smoking status } \\
\text { Non smoker } \\
\text { Ex-smoker } \\
\text { Current smoker }\end{array}$ & $\begin{array}{l}780 \\
422 \\
361\end{array}$ & $\begin{array}{l}49.9 \\
27.0 \\
23.1\end{array}$ & $\begin{array}{l}696 \\
380 \\
312\end{array}$ & $\begin{array}{l}50.1 \\
27.4 \\
22.5\end{array}$ & $\begin{array}{l}84 \\
42 \\
49\end{array}$ & $\begin{array}{l}48.0 \\
24.0 \\
28.0\end{array}$ & 0.24 \\
\hline $\begin{array}{l}\text { Body Mass Index, } \mathrm{kg} / \mathrm{m}^{2} \\
\quad<20 \\
\quad[20-25[ \\
\quad[25-30[ \\
\quad \geq 30\end{array}$ & $\begin{array}{l}149 \\
717 \\
383 \\
143\end{array}$ & $\begin{array}{l}10.7 \\
51.5 \\
27.5 \\
10.3\end{array}$ & $\begin{array}{l}145 \\
704 \\
379 \\
137\end{array}$ & $\begin{array}{l}10.6 \\
51.6 \\
27.8 \\
10.0\end{array}$ & $\begin{array}{c}4 \\
13 \\
3 \\
6\end{array}$ & $\begin{array}{l}14.8 \\
48.2 \\
14.8 \\
22.2\end{array}$ & 0.11 \\
\hline Ever asthma & 1571 & 43.5 & 1388 & 44.2 & 183 & 37.7 & 0.09 \\
\hline Current asthma & 630 & 88.6 & 572 & 88.8 & 58 & 86.2 & 0.55 \\
\hline $\begin{array}{l}\text { Asthma control } \\
\text { Controlled } \\
\text { Partly controlled } \\
\text { Uncontrolled }\end{array}$ & $\begin{array}{c}334 \\
179 \\
65\end{array}$ & $\begin{array}{l}57.8 \\
31.0 \\
11.2\end{array}$ & $\begin{array}{c}311 \\
169 \\
57\end{array}$ & $\begin{array}{l}57.9 \\
31.5 \\
10.6\end{array}$ & $\begin{array}{c}23 \\
10 \\
8\end{array}$ & $\begin{array}{l}56.1 \\
24.4 \\
19.5\end{array}$ & 0.19 \\
\hline Skin prick test positivity* & 1303 & 56.2 & 1281 & 56.3 & 22 & 50.0 & 0.56 \\
\hline Total IgE, $\geq 100 \mathrm{IU} / \mathrm{mL}$ & 1396 & 43.0 & 1383 & 43.0 & 13 & 46.1 & 0.82 \\
\hline FEV1 \% predicted, mean (SD) & 1387 & $102(18.0)$ & 1360 & $102(18.1)$ & 27 & $97.6(15.1)$ & 0.16 \\
\hline FEV1 $<80 \%$ predicted & 1387 & 9.60 & 1360 & 9.70 & 27 & 3.70 & 0.29 \\
\hline $\begin{array}{l}\text { Methacholine challenge**, } \\
\text { PD20 } \leq 4 \mathrm{mg}, \%\end{array}$ & 866 & 44.0 & 851 & 44.3 & 15 & 26.7 & 0.17 \\
\hline
\end{tabular}


Table E2: Levels of biomarkers of response according to sociodemographic characteristics among participants without ever asthma (N=774).

\begin{tabular}{|c|c|c|c|c|c|c|c|c|c|}
\hline & \multicolumn{3}{|c|}{ Catalase (k/g) } & \multicolumn{3}{|c|}{ GPX (U/g) } & \multicolumn{3}{|c|}{ SOD (U/g) } \\
\hline & $\mathrm{n}$ & Mean (SD) & $\begin{array}{l}\mathrm{p} \\
\mathrm{p}_{\text {adjusted }}\end{array}$ & $\mathrm{n}$ & GM (Q1. Q3) & $\begin{array}{l}\mathrm{p} \\
\mathrm{p}_{\text {adiusted }}\end{array}$ & $\mathrm{n}$ & GM (Q1. Q3) & $\begin{array}{l}\mathrm{p} \\
\mathrm{p}_{\text {adiusted }} *\end{array}$ \\
\hline \multicolumn{10}{|l|}{ Age (years) } \\
\hline$[16-25[$ & 93 & $169(34.6)$ & & 93 & $38.9(33.7 ; 44.0)$ & & 93 & $1265(1083 ; 1517)$ & \\
\hline$[25-35[$ & 133 & $154(44.2)$ & $\mathbf{0 . 0 3}$ & 134 & $37.0(32.5 ; 42.5)$ & 0.001 & 134 & $1260(1083 ; 1511)$ & 0.01 \\
\hline$[35-45[$ & 93 & $163(38.6)$ & 0.04 & 96 & $38.9(33.3 ; 44.0)$ & 0.01 & 96 & $1244(1044 ; 1509)$ & 0.003 \\
\hline$[45-55[$ & 181 & $168(34.9)$ & & 182 & $40.6(35.7 ; 46.7)$ & & 182 & $1204(1206 ; 1413)$ & \\
\hline$\geq 55$ & 262 & $162(40.8)$ & & 266 & $40.1(35.0 ; 46.4)$ & & 265 & $1170(960 ; 1410)$ & \\
\hline $\mathrm{p}$ for trend adjusted* & & & 0.94 & & & 0.01 & & & $<0.0001$ \\
\hline \multicolumn{10}{|l|}{ Sex } \\
\hline Men & 349 & $163(39.4)$ & 0.77 & 349 & $37.8(33.1 ; 43.8)$ & $<0.0001$ & 350 & $1226(1027 ; 1474)$ & 0.31 \\
\hline Women & 413 & $164(39.3)$ & 0.30 & 420 & $40.7(35.7 ; 46.7)$ & $<0.0001$ & 420 & $1204(1021 ; 1453)$ & 0.71 \\
\hline \multicolumn{10}{|l|}{ BMI $\left(\mathrm{kg} / \mathrm{m}^{2}\right)$} \\
\hline$<20$ & 71 & $165(33.9)$ & & 71 & $39.8(35.4 ; 44.8)$ & & 71 & $1194(1009 ; 1421)$ & \\
\hline$[20-25[$ & 376 & $160(39.7)$ & 0.07 & 382 & $39.2(33.8 ; 45.7)$ & 0.87 & 382 & $1193(1011 ; 1411)$ & 0.28 \\
\hline$[25-30[$ & 226 & $165(41.1)$ & 0.06 & 227 & $39.7(35.1 ; 45.8)$ & 0.62 & 228 & $1232(1034 ; 1470)$ & 0.02 \\
\hline$\geq 30$ & 76 & $171(37.1)$ & & 76 & $39.6(35.8 ; 45.2)$ & & 76 & $1247(1034 ; 1606)$ & \\
\hline $\mathrm{p}$ for trend adjusted* & & & 0.02 & & & 0.73 & & & 0.003 \\
\hline \multicolumn{10}{|l|}{ Smoking status } \\
\hline Non smoker & 380 & $159(39.3)$ & & 385 & $39.6(34.9 ; 44.8)$ & & 386 & $1216(1022 ; 1474)$ & \\
\hline Ex-smoker & 225 & $167(40.0)$ & 0.02 & 225 & $39.7(34.0 ; 46.5)$ & 0.13 & 225 & $1190(1028 ; 1441)$ & 0.24 \\
\hline Current smoker & 157 & $167(37.7)$ & 0.02 & 159 & $38.2(33.6 ; 44.0)$ & 0.59 & 159 & $1242(1033 ; 1452)$ & 0.42 \\
\hline $\mathrm{p}$ for trend adjusted* & & & 0.004 & & & 0.47 & & & 0.70 \\
\hline
\end{tabular}

GPX: glutathione peroxidase; SOD: superoxide dismutase; GM: geometric mean; BMI: Body Mass Index.

*Results were adjusted for age, sex and smoking status. 
Table E3: Levels of biomarkers of damage according to sociodemographic characteristics among participants without ever asthma $(\mathrm{N}=774)$.

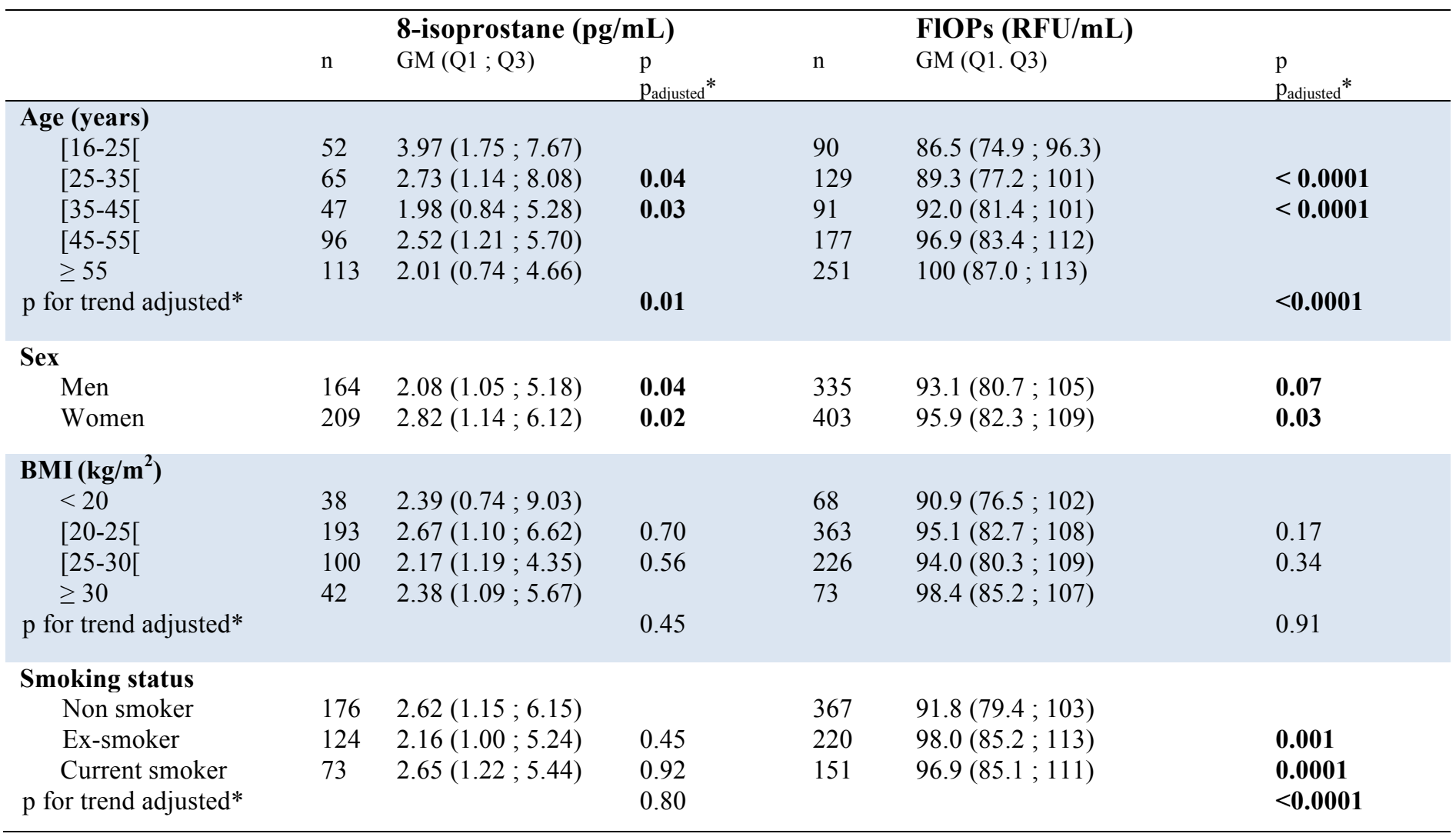

FlOPS : Fluorescent oxidation products ; GM: geometric mean ; BMI: Body Mass Index.

*Results were adjusted for age, sex and smoking status. 
Table E4: Associations between biomarkers of response related to oxidative stress, asthma and various asthma outcomes.

\begin{tabular}{|c|c|c|c|c|c|c|c|c|c|}
\hline & \multicolumn{3}{|c|}{ Superoxide dismutase (U/g) } & \multicolumn{3}{|c|}{ Glutathione peroxidase (U/g) } & \multicolumn{3}{|c|}{ Catalase (k/g) } \\
\hline & $\mathrm{n}$ & OR $(95 \% \mathrm{CI})^{*}$ & $\mathrm{OR}_{\text {adjusted }}(95 \% \mathrm{CI})^{*}$ & $\mathrm{n}$ & OR $(95 \% \mathrm{CI})^{*}$ & $\mathrm{OR}_{\text {adjusted }}(95 \% \mathrm{CI})^{*}$ & $\mathrm{n}$ & OR $(95 \% \mathrm{CI})^{*}$ & $\mathrm{OR}_{\text {adjusted }}(95 \% \mathrm{CI})^{*}$ \\
\hline $\begin{array}{l}\text { Asthma ever } \\
\text { (vs never asthma) }\end{array}$ & 1377 & $1.04(0.91 ; 1.20)$ & $0.96(0.83 ; 1.12)$ & 1378 & $0.91(0.81 ; 1.03)$ & $1.01(0.89 ; 1.15)$ & 1368 & $0.97(0.84 ; 1.11)$ & $0.97(0.85 ; 1.12)$ \\
\hline \multicolumn{10}{|l|}{$\begin{array}{l}\text { Among participants } \\
\text { with ever asthma }\end{array}$} \\
\hline $\begin{array}{l}\text { Current asthma } \\
\text { (vs without current) } \\
\text { asthma }\end{array}$ & 567 & $1.04(0.74 ; 1.46)$ & $1.08(0.76 ; 1.54)$ & 568 & $0.85(0.62 ; 1.17)$ & $0.83(0.59 ; 1.15)$ & 565 & $0.96(0.66 ; 1.38)$ & $0.93(0.64 ; 1.35)$ \\
\hline $\begin{array}{l}\text { Asthma attacks in the } \\
\text { last } 12 \text { months }\end{array}$ & 604 & $0.95(0.68 ; 1.21)$ & $0.91(0.64 ; 1.19)$ & 606 & $0.95(0.74 ; 1.15)$ & $0.90(0.68 ; 1.11)$ & 603 & $1.10(0.88 ; 1.32)$ & $1.13(0.91 ; 1.35)$ \\
\hline $\begin{array}{l}\text { Poor asthma control** } \\
\text { (vs controlled asthma) }\end{array}$ & 532 & $0.87(0.67 ; 1.13)$ & $0.91(0.70 ; 1.19)$ & 533 & $0.87(0.70 ; 1.09)$ & $0.82(0.65 ; 1.04)$ & 530 & $1.00(0.79 ; 1.28)$ & $1.01(0.79 ; 1.29)$ \\
\hline $\begin{array}{l}\text { FEV }_{1}<80 \% \\
\text { predicted }^{*} *\end{array}$ & 596 & $0.98(0.69 ; 1.40)$ & $1.15(0.77 ; 1.73)$ & 598 & $1.21(0.93 ; 1.57)$ & $1.12(0.84 ; 1.50)$ & 595 & $1.04(0.77 ; 1.39)$ & $1.02(0.76 ; 1.36)$ \\
\hline
\end{tabular}

*OR expressed for an increase corresponding to the value of the interquartile range (distance between the $25^{\text {th }}$ and $75^{\text {th }}$ percentile) of each biological marker;

Results were adjusted for age, sex and smoking status; **Results were unchanged when restricting analyses to participants with current asthma;

$\mathrm{FEV}_{1}$ : Forced expiratory volume in one second. 